\title{
Komparace formálního ukotvení terénní výuky ve školních vzdělávacích programech a její pojetí v modelových základních školách ${ }^{1}$
}

\author{
Hana Svobodová, Radek Durna, \\ Darina Mísařová, Eduard Hofmann \\ Masarykova univerzita, Pedagogická fakulta
}

\begin{abstract}
Abstrakt: Terénní výuka je jednou z forem výuky, která je zařazována do vyučovacího procesu základních i středních škol. Její formální i procesuální stránka je však značně opomíjená a v české literatuře velmi okrajově řešena. Autoři př́spěvku vycházejí z předpokladu, že zařazení terénní výuky do vyučovacího procesu je ve většině škol nekoncepční. Předkládaná studie analyzuje pojetí terénní výuky ve vybraných základních školách v Česku. V první fázi výzkumu byla učiněna obsahová analýza školních vzdělávacích programů (dále jen ŠVP) ve vztahu k terénní výuce na vzorku 50 škol. Cílem bylo analyzovat zejména formální stránku výuky v terénu na daných školách, tj. identifikovat jednotlivé formy terénní výuky, dílčí témata a obsahovou návaznost výuky $v$ terénu, ucelenost koncepce, ale také např. časovou náročnost terénní výuky či její integrující charakter (mezipředmětovost). Druhá fáze výzkumu - strukturované rozhovory s učiteli na devíti modelových základních školách - upřesňuje a prohlubuje výsledky první fáze výzkumu. Tyto školy byly vybrány na základě poznatku, že terénní výuka je $v$ dané škole dlouhodobě realizována ve všech námi sledovaných formách. Analýza ŠVP ukázala, že se jednotlivé dokumenty liší zejména rozsahem zpracování obsahové části konkrétních předmětů, přičemž právě u zařazení různých forem terénní výuky co do kvantity a kvality bylo zjištěno nejvíce odlišností. Rozhovory s učiteli tyto rozdíly potvrdily a poukázaly na řadu dalších informací z ŠVP nezjistitelných.
\end{abstract}

Klíčová slova: základní škola, terénní výuka, školní vzdělávací program, strukturovaný rozhovor, učitel

\section{Comparison Between Formal Anchoring of Outdoor Education in School Curriculum and Its Conception on Model Elementary Schools}

Abstract: The outdoor education is an educational form that can be included in the teaching process at elementary and secondary schools. What remains often neglected (and what is marginalized in (zech literature) is both formal and procedural part of outdoor education. The authors of this paper assume that the inclusion of outdoor education in the teaching process is inconceivable in most Czech schools. The presented study analyses the conception of outdoor education at selected primary schools in Czechia. The first phase of research consists of the content analysis of School Education Programs (SEP, i.e. school curricula). This analysis was made in relation to outdoor education on a sample of 50 schools from Czechia. The aim of this step was to analyse the formal part of the outdoor education at selected schools. It means to identify both partial forms of outdoor education and partial educational themes as well as the educational connection of the content of school learning (traditionally indoor) and outdoor education. Time management of outdoor education, its overall concept and the interdisciplinary character was further investigated. The next phase of our research - the structured interview with teachers at nine model

1 Příspěvek vznikl v rámci projektu GA ČR 16-00695S „Terénní výuka jako silná výuková strategie“ řešeného v letech 2016-2018. 
96 elementary schools - specifies and deepens the above described results achieved in the first phase. Interviews were conducted with 18 teachers ( 9 of them teaching at the first stage of elementary school and 9 teaching at the second stage of elementary school). Selection of these schools was based on the knowledge that the outdoor education has been implemented in these schools continuously for many years, using different forms of outdoor education (both of this was identified in SEPs). The analysis of SEPs showed that the SEP particularly differs by the extent of the description of individual teaching subjects and their content. The most differences were found in the various forms of outdoor education, in terms of quantity and quality of learning. Subsequent interviews with teachers have confirmed these differences, on the other hand, the results have pointed to several additional information which is not possible to obtain in any other way.

Keywords: elementary school, outdoor education, school curriculum, structured interview, teacher

Terénní výuku chápeme jednak jako jednu z organizačních forem výuky (viz např. Průcha, Walterová, \& Mareš, 2013, s. 183), jednak jako silnou výukovou strategii (kupř. Lambert \& Balderstone, 2010), která umožňuje komplexněji chápat reálný svět. $V$ anglicky psané odborné literatuře se $\mathrm{k}$ souhrnnému pojmenování „terénní výuky“ nejčastěji užívá pojmů outdoor education/learning či fieldwork (viz např. Biddulph, Lambert, \& Balderstone, 2015; Kent, Gilbertson, \& Hunt, 1997; Lambert \& Reiss, 2014; Ofsted, 2011; Oost, De Vries, \& Van der Schee, 2011; nebo Rickinson et al., 2004). Lambert a Reiss (2014) uvádějí, že pojem fieldwork může být chápán jako kterákoli součást kurikula, která zahrnuje jednak opuštění prostoru klasické školní třídy, jednak aktivity vedoucí k naplnění výchovně-vzdělávacích cílů prostřednictvím vlastnoručně nabytých zkušeností (first hand experiences) a využívá přitom fenoménu výuky „pod širým nebem“ (out of door). Na Slovensku se výzkumem výuky v terénu zabývali bliže např. Kvasničák, Prokop a Pištová (2005) či Kvasničák (2013), kteří ji označují jako terénne skúsenostne vyučovanie a řadí ji do neformálního vyučování. V české literatuře popisuje Řezničková $(2008$, s. 10) výuku v krajině, upozorňuje na neustálenost definice takové výuky a nabízí další pojmy: výuka $\checkmark$ (městské/venkovské) krajině, výuka v terénu, terénní vyučování, terénní výuka, terénní cvičení, exkurze, naučná vycházka či geografická laboratoř. Marada (2006, s. 2) k neustálenosti definice terénní výuky a jejích jednotlivých forem dodává, že tyto termíny vesměs nejsou přesně definovány a jejich obsah je obecně vnímán spiše intuitivně. Terminologickou nejednotnost uvádí shodně i Záleský (2009, s. 14), který zdůrazňuje hlavní přínosy terénní výuky, která by neměla být odtržena od výuky ve škole, ale naopak by měla být její samozřejmou součástí.

Přestože se $s$ terénní výukou $v$ našem vzdělávacím systému počíá, viz např. tematické celky RVP ZV učiva př́rodopisu (Praktické poznávání př́rody) a zeměpisu (Terénní geografická výuka, praxe a aplikace), jak již bylo uvedeno, není tento pojem v české literatuře dosud přesně definován. Proto jej pro účely našeho výzkumu vymezujeme na základě definice Hofmanna et al. $(2003$, s. 7) následovně:

Terénní výuku definujeme jako „zastřešující“ pojem pro rozmanité formy výuky, jejichž společným rysem je realizace $v$ terénu, mimo budovu školy. Terénní výuka může nabývat rozmanitých organizačních forem od vycházky, přes exkurze, terénní cvičení až po terénní výzkum. Pokud má mít jakákoli forma terénní výuky 
pro žáky př́nos, musí být žáci v průběhu terénní výuky badateli aktivně shromažd'ujícími a zpracovávajícími informace z primárních i sekundárních zdrojů, za pomoci výzkumných metod a pomůcek jednotlivých vědních disciplín.

Přikláníme se k názoru výše zmíněných autorů, kteří považují terénní výuku v „reálném světě“ za naprosto zásadní (essential) součást přirodovědného vzdělávání, jelikož rozvíjí dovednosti nutné k pochopení samotné podstaty této oblasti lidského/žákovského bádání. Podobně považují terénní výuku za nedílnou součást prírodovědného vzdělávání také např. Kent et al. (1997), podle nichž je terénní výuka nejenom velmi efektivní, ale také př́jemná forma výuky, a to pro všechny účastníky výchovně-vzdělávacího procesu. Na význam terénní výuky ve smyslu silné výukové strategie poukazují i autoři z Nizozemska (Oost et al., 2011), kteří pro účely svého výzkumu definují terénní výuku jako „podnikání výukových aktivit ve venkovním prostředí“ (in outdoor setting), spojených s konkrétními obsahy kurikula. Oostová se spolupracovníky (2011) se dále ztotožňují s názory Rickinsona et al. (2004), kteří uvádějí, že promyšlená a smysluplně provedená terénní výuka, zařazená $v$ návaznosti na předešlé (potažmo následující) učivo, poskytuje žákům nové príležitosti k rozvoji znalostí a dovedností a dodává jejich každodenním zkušenostem z vyučování přidanou hodnotu.

\section{Koncepce terénní výuky $v$ základních školách}

V předchozí části jsme stručně načrtli přistupy $\mathrm{k}$ definování terénní výuky a význam jejího řazení do školního kurikula v zahraničí i v Česku. Pro lepší vysvětlení naší výzkumné potřeby i zvolené metodologie výzkumu je nutné si v krátkosti představit také zamýšlený návrh koncepce terénní výuky pro základní školy. $V$ obecné rovině považujeme za koncepci vyučování pojetí formální i procesuální stránky vyučování, které se v pedagogické praxi odráži v podobě výběru cílů, obsahu, podmínek, zásad, organizačních forem, prostředků a metod vyučování a $v$ pojetí vztahu učitele a žáka ve výuce (Kratochvíl, Solfronk, \& Urbánek 2002; Petty, 1996; Průcha, 1992). Vzhledem $\mathrm{k}$ rozsáhlosti problematiky se $\mathrm{v}$ příspěvku věnujeme více formální stránce terénní výuky, tedy vnějšímu usporádání podmínek výuky (viz tabulka 2), procesuální stránka (obsah, didaktické zásady a metody) není detailně analyzována.

Tento návrh se opírá o dlouhodobé zkušenosti s terénní výukou uplatňovanou při prípravě budoucích učitelů na Pedagogické fakultě Masarykovy univerzity. Vychází zejména ze zkušeností s oborovou terénní výukou v případech učitelství: zeměpisu, prírodopisu, chemie, fyziky, dějepisu, tělesné výchovy a také ze zkušeností s integrovanou terénní výukou, která v duchu posilování mezipředmětových vazeb propojuje zmíněné obory s dalšími (Hofmann, Rychnovský, \& Borecký, 1999; Hofmann et al., 2003). Typicky se jedná o obory český jazyk, cizí jazyk, matematiku, informační a komunikační technologie a občanskou výchovu.

Významný potenciál terénní výuky lze spatřovat $v$ možnostech aplikace již osvojeného učiva na konkrétní situace $v$ reálném prostředí, kdy vhodným zakomponová- 
98 ním učebních a praktických úloh je možné učivo prohlubovat a obohacovat. Tohoto efektu lze dosáhnout za splnění podmínky vhodného zařazení dílčích forem terénní výuky do předem promyšleného systému/koncepce terénní výuky (Oost et al., 2011; Rickinson et al., 2004). Aby řazení terénní výuky mezi ostatní formy výuky nebylo nahodilé (s žádnými nebo minimálními návaznostmi na ostatní výukové formy), je žádoucí při tvorbě koncepce pamatovat na následující zásady.

Návaznost terénní výuky na učivo předchozích ročníků a progresi učiva. Jednotlivé formy terénní výuky (viz tabulka 1 ) by měly být do výuky zařazeny podle schématu progrese učiva (viz např. Mrázková, 2011, na př́íladu kartografických dovedností), aby tak postupně rozvíjely dílči dovednosti a kompetence žáků, a to jak v horizontálním, tak vertikálním pojetí. Horizontální řazení vyjadřuje progresi obtížnosti jednotlivých činností, to znamená, že ze začátku školního roku učitel zařazuje takové formy terénní výuky, které pomáhají žákům zvládnout jednodušší činnosti, a postupně přidává činnosti složitější a komplexnější. Ve vertikálním pojetí máme na mysli návaznost učiva $v$ jednotlivých ročnících a prohlubování již dřive naučených činností. V nižších ročnících jsou tedy v rámci terénní výuky zařazovány jednoduché činnosti, které zadává učitel. $K$ těmto činnostem se ve vyšších ročnících přidávají aktivity vyžadující nejen znalosti předchozích činností, ale i větší samostatnost žáka. $\checkmark$ poslední fázi je pak žák schopen samostatně pracovat $v$ terénu a role učitele je spíše kontrolní. Role žáka se tak mění od tradičního spotřebitele informací k aktivnímu učíímu se člověku. Obě role, jak učitele, tak studenta, jsou mezi sebou vyvážené, výuka je bud' více zaměřena na vedení učitelem, nebo je více orientována na práci studenta (Oost et al., 2011, s. 311).

Tabulka 1 Činnosti definující základní formy terénní výuky a jejich progresi

\begin{tabular}{llll}
\hline Forma terénní výuky & Exkurze & Vycházka & Terénní cvičení \\
\hline Podle činností & pozorování & pozorování & pozorování \\
& kladení cílených & kladení cílených & kladení cílených \\
& otázek & otázek & otázek \\
& vedení terénního & sběr & měrení \\
& deníku & popisování & mapování \\
& (zaznamenávání) & kreslení (náčrty) & šetření (dotazníkové) \\
& foto- a (video) & orientace & analyzování \\
& dokumentace & foto- (a video-) & hodnocení \\
& & dokumentace & foto- a (video) \\
& & vedení terénního & dokumentace \\
& & deníku & vedení terénního \\
& & (zaznamenávání) & deníku \\
& & (zaznamenávání) \\
\hline
\end{tabular}

Poznámka: Kurzivou jsou označeny průřezové činnosti vyskytující se u všech forem terénní výuky.

Propojenost a přimá návaznost na výuku $v$ učebně. Propojením terénní výuky s výukou ve třídě lze dosáhnout efektivnějšího upevnění učiva (podrobněji viz např. 
Činčera \& Holec, 2016; Kvasničák, 2013; Rickinson et al., 2004). Propojení terénní výuky s výukou $v$ učebně vychází i z celkové organizace terénní výuky, která v sobě zahrnuje tř́i základní fáze výuky: př́ipravnou - probíhá zpravidla ve tř́dě jako součást běžné výuky, realizační - uskutečňuje se v terénu, hodnotící - může proběhnout i v terénu a je vhodné na ni navázat $v$ další výuce ve trí́dě.

Propojenost různých forem terénní výuky z hlediska jejího trvání. Autoři pracují s vlastním rozdělením časových forem: Krátkodobé formy terénní výuky probíhající zpravidla v bezprostředním okolí školy, na školním pozemku nebo ve venkovní učebně/laboratoři a nepřesahující více než dvě vyučovací hodiny. Za střednědobé označujeme takové formy, které jsou zpravidla realizovány $v$ blízkosti školy nebo na území přislušné obce, kde se škola nachází. Do této kategorie řadíme i exkurze do podniků či školských/mimoškolních zařízení. Jejich trvání může přesáhnout čas, který je vyčleněn pro výuku, protože je často nutné započítat např. čas potřebný k dopravě do lokality a zpět. Obvykle se jedná o jeden vyučovací den. Dlouhodobé formy jsou pak ty, které probíhají dva a více vyučovacích dní a často zahrnují i přespání mimo domov. Výuka tak může probíhat vícero dní soustředěnou formou (intenzivní kurz) nebo tzv. etapově, pokud je předmětem zájmu např. dlouhodobější pozorování či měření konkrétního jevu. U dlouhodobých forem terénní výuky je z hlediska koncepce žádoucí, aby při jejich př́pravě a realizaci docházelo $k$ zúročení dovedností, návyků a zkušeností získaných z nácviku jednotlivých činností z krátkoa střednědobých forem. Těžiště činnosti žáků při dlouhodobých formách terénní výuky by mělo ležet především v badatelsky orientované výuce (inquiry-based education), viz např. Karvánková et al. (2017) nebo Samková et al. (2015), realizované prostřednictvím samostatné a skupinové práce.

Komplexnější a dlouhodobější formy terénní výuky mohou zahrnovat tematicky užší a krátkodobější formy terénní výuky. Např́iklad součástí terénního cvičení může být vycházka. Důležité je, aby veškeré formy terénní výuky měly vždy stanovené vzdělávací cíle (s př́padnými výstupy - mapa, náčrt, pracovní list). Tímto učitel jednak zdůvodní zařazení př́slušné formy terénní výuky do tematického výukového plánu a jednak předejde možným nařčením typu: vycházka je „pouhou“ relaxací apod.

Propojenost aktuálních témat s terénní výukou v různých typech krajiny. Další kritérium klasifikace terénní výuky je tvořeno charakteristikami prostoru/území, ve kterém je tato výuka realizována. Na nejvyšší úrovni rozlišujeme výuku ve venkovské nebo městské krajině (Řezníčková, 2008).

Venkovská krajina se dále rozlišuje (Jelínek \& Kysučan, 2014) na prírodě blízkou (listnatý/smíšený les, louka, pastvina) nebo více či méně pozměněnou lidskou činností (monokultura smrku, agrokultura polních plodin). Člověkem velmi silně pozměněná městská krajina je pro účely terénní výuky reprezentována bud' přímo celým územím sídla, nebo jeho vybranou částí (např. čtvrt', areál podniku, brownfield, park). 
Terénní výuka je velmi specifická výuková forma a její prínos nespočívá pouze v kognitivní oblasti, ale má význam i pro afektivní stránku výchovy a vzdělání a podporuje i vzájemnou komunikaci a interpersonální vztahy (Smetáčková, 2011). Rozvíjí u žáků různé druhy dovedností spojené především s praktickými činnostmi v krajině a ve své podstatě se prolíná celým kurikulem základní i střední školy.

Širši mezioborový pohled na terénní výuku přináší metaanalýza autorů Činčery a Holce (2016), která na základě studia více než 70 především zahraničních studií shrnuje dopady terénní výuky na žákovské znalosti, postoje, dovednosti, přesvědčení a chování. Ukazuje se tak, že zatímco v zahraničí je terénní výuka považována za silnou výukovou strategii (např. Hopkins, 2000; Tejeda \& Santamaría, 2010) a je jí věnována náležitá pozornost jak v samotném procesu vyučování, tak ve výzkumné a publikační činnosti, $v$ Česku hledáme komplexní výzkum $v$ oblasti terénní výuky poměrně obtížně. Procesuální stránka terénní výuky není až na několik dílčích studií (např. Činčera, 2011; Činčera \& Mašková, 2011; Žák, 2011) blíže řešena, chybí opakované výzkumy posuzující a hodnotící efektivnost této formy výuky. Nemáme také povědomí o zařazení terénní výuky do školních vzdělávacích programů a o jejím pojetí na základních ani středních školách. Tohoto výzkumu se týká jen studie Knechta a Hofmanna (2013). Z tohoto deficitu pramení výzkumná potřeba autorů realizovaná v rámci projektu GA ČR 16-00695S „Terénní výuka jako silná výuková strategie“.

Jedním z dílčích cílů tohoto projektu a také cílem následujícího příspěvku je zjistit, jak je terénní výuka řazena do výuky ve vybraných základních školách v Česku z hlediska prostoru, času, vazby na učivo probírané ve třídě a progresi učiva $v$ jednotlivých ročnících (blíže viz oddíl 1 ). Vzhledem $k$ výše navrženým zásadám terénní výuky je výzkumná otázka $\mathrm{k}$ uvedenému dílčímu cíli výzkumu formulována následovně: Je formální stránka terénní výuky na základní škole pojata koncepčně?

\section{Metody sběru a analýzy dat}

První fází výzkumu byla obsahová analýza školních vzdělávacích programů (ŠVP) ve vztahu k terénní výuce, tedy analýza projektovaného kurikula. Podle předem stanovených otevřených, polouzavřených a uzavřených otázek (Hendl, 2012), respektive kritérií, bylo zjišt’ováno, zda a v jakých formách je terénní výuka uvedena v učebních osnovách a učebních plánech. Hodnocené parametry byly vybrány dle obsahového, časového, lokalizačního a organizačního hlediska (podrobněji viz dále). Byla určena úroveň analýzy, tzn. jednotlivé koncepty (kategorie), mezi které byly zařazeny slova, fráze či témata. Následoval návrh kódování, tedy uvedení jednotek v dílčích kategoriích $s$ upřesněním šíře jednotlivých konceptů. Zaznamenávaly se existence a frekvence výskytu slov či frází. Napríklad pokud bylo v ŠVP u charakteristiky předmětu uvedeno „výuka probíhá pomocí různých forem a metod $v$ závislosti na charakteru učiva - frontální výuka, skupinová práce, projekty, referáty, zeměpisné 
exkurze“ a následně definován pro daný předmět výstup „zná základní orientaci $v$ terénu podle buzoly a mapy“, byly přiřazeny tyto kódy: zařazení $v$ učebním plánu - ano, z hlediska předmětového - předmětová terénní výuka, z hlediska časového krátkodobá terénní výuka, z hlediska prostoru - prostředí obce nebo školní pozemek (což vychází z krátkodobosti aktivity a znalosti této souvislosti u osoby kodéra), z hlediska organizačního (formy) - exkurze/vycházka (zde nelze jednoznačně určit, orientace je spíše náplní vycházky nebo terénního cvičení). Takto byl okódován kompletní ŠVP dané školy a $v$ závěru bylo zhodnoceno, zda je terénní výuka $v$ ŠVP představena jako ucelená koncepce, a to jak hodnocením ano $\times$ ne, tak stručným slovním komentářem.

Druhá fáze výzkumu měla upřesnit a prohloubit výsledky zjištěné v první fázi (obsahová analýza) pomocí strukturovaných rozhovorů s učiteli na 1. i 2. stupni základních škol. Autoři výzkumu jsou si vědomi toho, že formální obsah ŠVP nemusí vždy zcela odrážet realitu dané školy, a proto se uchýlili k triangulaci (Creswell \& Plano Clark, 2011; Hendl, 2012). Strukturované rozhovory s řadou učitelů umožnily proniknout hlouběji do řešené problematiky zakotvení terénní výuky do ŠVP, a především do edukační reality, tedy do realizovaného kurikula.

Jak uvádí Hendl (2012, s. 173), „základním účelem tohoto typu interview (pozn. strukturované rozhovory) je co nejvíce minimalizovat efekt tazatele na kvalitu rozhovoru ... Tento typ rozhovoru je vhodný, pokud ho nemáme možnost opakovat “. Každý respondent byl tedy dotazován na stejné otázky přesně ve stejném pořadí (Hay, 2010). Většina otázek byla na úvod formulována jako uzavřená, kdy měli učitelé možnost vyjádřit se $k$ otázce pouze ANO nebo NE a až následně bylo požadováno vysvětlení této odpovědi a rozvedení tématu prostřednictvím otevřené otázky. Záměrem „rozděleni“ otázky na uzavřenou a otevřenou část bylo kvantitativní hodnocení první části otázky (počet odpovědí ANO × NE; kvantitativní vyjádření je uváděno pro přehlednost výsledků) a následně snazší kategorizace otevřených odpovědí. Rozhovory byly zaznamenány písemně a zároveň po vyjádření souhlasu dotazovaných i nahrávány na diktafon.

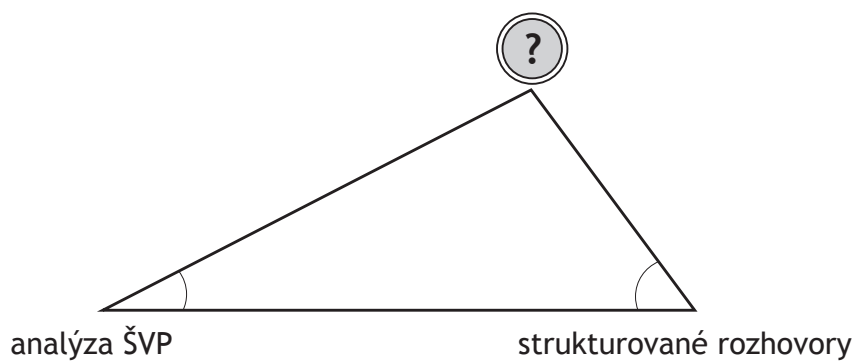

Obrázek 1 Schematické znázornění triangulace metod. $V$ popředí leží užité metody sběru dat, slabě jsou naznačeny odlišné úhly pohledu na problematiku (získané optikou odlišných metod) a v pozadí se rýsuje nové poznání (?), které je konstruováno triangulací metod získávání dat. 

hovory (druhá fáze výzkumu) prohloubeny zejména v následujících oblastech (viz tabulka 2).

Tabulka 2 Transformace zájmových témat vyplývajících z analýzy ŠVP do dotazníku pro strukturovaný rozhovor

\begin{tabular}{|c|c|}
\hline $\begin{array}{l}\text { Zájmová oblast vyplývající } \\
\text { z obsahové analýzy ŠVP }\end{array}$ & $\begin{array}{l}\text { Otázky z rozhovoru s učitelem (odpověd’: ANO - NE, } \\
\text { svoji odpověd' zdůvodněte, popř. okomentujte) }\end{array}$ \\
\hline koordinace terénní výuky & $\begin{array}{l}\text { Máte vy nebo jiný učitel či zástupce vedení školy } \\
\text { přehled o všech uskutečňovaných formách terénní } \\
\text { výuky realizovaných na vaši škole? } \\
\text { Koordinuje někdo na vaší škole všechny formy terénní } \\
\text { výuky tak, aby tvořily ucelenou koncepci², která na } \\
\text { sebe navazuje? }\end{array}$ \\
\hline ucelenost koncepce terénní výuky & $\begin{array}{l}\text { Máte ve svých předmětech utvořenu ucelenou koncepci } \\
\text { terénní výuky? }\end{array}$ \\
\hline výběr témat pro terénní výuku & Máte nějaký způsob výběru témat pro terénní výuku? \\
\hline realizované formy terénní výuky & $\begin{array}{l}\text { Využiváte ve vámi vyučovaných předmětech různé } \\
\text { formy terénní výuky? }\end{array}$ \\
\hline orientační hodinová náročnost & $\begin{array}{l}\text { Jsou všechny formy terénní výuky zapracované } \\
\text { do ročního tematického plánu vašeho předmětu } \\
\text { s vyjádřením hodinové dotace? }\end{array}$ \\
\hline mezipředmětovost & $\begin{array}{l}\text { Realizujete některé formy terénní výuky ve spolupráci } \\
\text { s učiteli jiných vzdělávacích předmětư? }\end{array}$ \\
\hline návaznost terénní výuky & $\begin{array}{l}\text { Vybíráte témata v př́mé návaznosti na výuku ve škole? } \\
\text { Vybíráte pro terénní výuku konkrétní náměty z reálného } \\
\text { života? } \\
\text { Máte zakotvenou terénní výuku i v „neformálním } \\
\text { kurikulu“? Napřiklad v zájmových kroužcích? } \\
\text { Realizujete terénní výuku zprostředkovanou výukovými } \\
\text { programy jiných organizací než školy? } \\
\text { Využíváte forem terénní výuky v dalších vzdělávacích } \\
\text { akcích? }\end{array}$ \\
\hline příprava učitele na výuku $v$ terénu & Děláte si podrobné přípravy na terénní výuku? \\
\hline bariéry realizace terénní výuky & $\begin{array}{l}\text { Cítíte vy osobně nějaká omezení při príípravě terénní } \\
\text { výuky? }\end{array}$ \\
\hline pomůcky pro terénní výuku & $\begin{array}{l}\text { Máte ve vaší škole možnost zapůjčení potřebných } \\
\text { pomůcek pro terénní výuku? }\end{array}$ \\
\hline
\end{tabular}

Poznámka: Vzhledem k omezenému rozsahu př́spěvku jsou zde uvedeny pouze vybrané výsledky strukturovaného rozhovoru (viz oddíl 5.2).

Zvukové nahrávky rozhovorů byly přepsány do textové podoby formou doslovné transkripce. Tyto přepisy pak byly výzkumníky opakovaně pročítány a jednotlivé vý-

2 Učitelé byli před rozhovorem seznámeni s pojetím koncepce terénní výuky a dílčími hledisky této koncepce (viz oddíl Koncepce terénní výuky v základních školách). 
povědi byly řazeny do relevantních kategorií podle obsažené informace (koordinace, koncepčnost, ucelenost, návaznost, mezipředmětovost atd., viz tabulka 2). Nakonec bylo možné na základě syntézy dílčích výroků $z$ analyzovaných rozhovorů formulovat závěry $\mathrm{k}$ jednotlivým aspektům terénní výuky $\mathrm{v}$ modelových školách.

\section{Výzkumný soubor}

Výběr modelových škol pro analýzu ŠVP (první fáze výzkumu) byl proveden záměrným výběrem (Gavora, 2000, s. 60), který se uskutečnil na základě kvalifikovaného relevantního znaku - a to vědomí autorů, že v modelové škole jsou během školního roku do výuky řazeny různé formy terénní výuky. Záměrný výběr byl proveden i s ohledem na fakt, že výzkum je orientovaný kvalitativně a nebylo zapotřebí zvětšovat počet modelových škol za účelem „zlepšeni“ vlastností analyzovaného souboru. Obsahová analýza ŠVP proběhla u 50 škol z Jihomoravského a Jihočeského kraje.

$\checkmark$ druhé fázi výzkumu bylo vzhledem $k$ časové náročnosti realizace šetření včetně jeho vyhodnocení zvoleno devět modelových škol, které měly v ŠVP ( v první fázi výzkumu) zastoupeny různé formy terénní výuky a hodnotitel ŠVP rozhodl při analýze, že terénní výuka je zastoupena „významně“ - to znamená, že je zmiňována ve více předmětech a jsou uvedeny i další aktivity jako např. terénní výcvikový kurz, ekologický pobyt, projekty spojené s pobytem $v$ terénu. Jednotlivé školy byly osloveny formou dopisu/e-mailu řediteli školy, který byl seznámen s cílem výzkumu a byl požádán o doporučení vhodné osoby pro realizaci rozhovoru. V některých školách následně probíhal rozhovor s učitelem 1. a 2. stupně odděleně vzhledem $\mathrm{k}$ jejich odlišným časovým možnostem, jinde se dotazování účastnily až čtyři osoby (zároveň učitelé 1. i 2. stupně). Tento formát rozhovoru lze považovat za „skupinovou diskusi“, kdy se uvolňují psychické zábrany (kolegové ve škole se dobře znají a často berou rozhovor i jako možnost pobavit se o výuce mezi sebou) a debatující snadněji i před neznámým tazatelem odhalují své postoje, názory, myšlení, zkušenosti (Hendl, 2012, s. 182). Základní identifikaci učitelů - pohlaví, délku pedagogické praxe a aprobaci uvádí tabulka 3.

Tabulka 3 výzkumný vzorek druhé fáze výzkumu $(n=18)$

\begin{tabular}{cccc|cccc}
\hline $\begin{array}{c}\text { Kód } \\
\text { učitele }\end{array}$ & Pohlaví & $\begin{array}{c}\text { Délka ped. } \\
\text { praxe }\end{array}$ & $\begin{array}{c}\text { Aprobace vyuč. } \\
\text { předmětů }\end{array}$ & $\begin{array}{c}\text { Kód } \\
\text { učitele }\end{array}$ & $\begin{array}{c}\text { Pohlaví } \\
\text { Délka ped. } \\
\text { praxe }\end{array}$ & $\begin{array}{c}\text { Aprobace vyuč. } \\
\text { předmětů }\end{array}$ \\
\hline 1 & žena & 25 & 1. st. + ZSV & 10 & žena & 4 & $\mathrm{Bi}, \mathrm{Ze}, \mathrm{Ch}$ \\
2 & žena & 21 & 1. st. + PV & 11 & muž & 11 & Ze \\
3 & žena & 32 & 1. st. & 12 & muž & 21 & $\mathrm{Př,} \mathrm{Tv,} \mathrm{Ma}$ \\
4 & žena & 20 & 1. st. & 13 & žena & 29 & $\mathrm{Rj}$, De, Ze \\
5 & muž & 12 & 1. st. & 14 & žena & 9 & $\mathrm{Nj}$, Pŕ \\
6 & žena & 15 & 1. st. + Aj & 15 & muž & 15 & Inf, Př, Ze \\
7 & žena & 32 & 1. st. & 16 & žena & 32 & 1. st., Enviro \\
8 & muž & 1 & 1. st. + spec. TV & 17 & muž & 11 & Fy \\
9 & žena & 18 & 1. st. & 18 & žena & 6 & Ze, Př \\
\hline
\end{tabular}


Rozhovory v druhé fázi výzkumu byly provedeny na vzorku 18 učitelů základních škol na území Jihomoravského a Jihočeského kraje. Z celkového počtu 18 učitelů jich devět učí na 1 . a devět na 2 . stupni.

\section{Výsledky šetření}

Výsledky obou fází výzkumu níže prezentujeme tak, jak fáze chronologicky postupovaly. Nejprve představíme zájmové oblasti analýzy ŠVP, poté se zaměŕíme na výsledky strukturovaného rozhovoru, jež jsou opět seřazeny dle zájmových oblastí.

\subsection{Obsahová analýza ŠVP}

Dostupnost a aktuálnost ŠVP. ŠVP většiny škol zahrnutých do výzkumu byl volně dostupný na webové stránce školy - z analyzovaného vzorku $(n=50)$ mělo ŠVP dostupný 42 škol, osm škol poslalo ŠVP na vyžádání. Aktuálnost ŠVP je u modelových škol různá. Nejstarší ŠVP byl zpracován v roce 2006, z roku 2007 jich pochází osm z celkových 50. Nejčastěji byly ŠVP zpracovány nebo aktualizovány v roce 2013 (18 škol), devět škol zpracovalo nebo aktualizovalo ŠVP v roce 2014 a čtyři v roce 2015. Stáří analyzovaných ŠVP poukazuje na fakt, že se nejedná o „živý“ dokument, který by učitelé každý rok aktualizovali. To potvrzuje i tematická zpráva České školní inspekce (2012, s. 9): „K tvorbě ŠVP přistoupily některé školy formálně...“

Ve všech analyzovaných ŠVP byla př́imo (např. pozorování v krajině) či nepřímo (kupř. orientace podle mapy) zmíněna terénní výuka. Subjektivně pak byla hodnocena míra zastoupení terénní výuky $\vee$ ŠVP. Ve 12 ŠVP je terénní výuka zastoupena hodně (je zmiňována ve více předmětech a jsou uvedeny i další aktivity, např. terénní výcvikový kurz, ekologický pobyt, projekty spojené s pobytem v terénu), v 18 středně a ve 20 ŠVP málo (terénní výuka $v$ jakékoli formě je zmiňována jen velmi okrajově). Zastoupení terénní výuky $v$ ŠVP mohlo napovědět mj. zaměření ŠVP na environmentální výuku apod.

Zařazení terénní výuky. Pro koordinaci terénní výuky a optimalizaci jejího systému je pro nás důležité, zda je terénní výuka $v$ ŠVP představena jako ucelená koncepce (výuky), to znamená, zda na sebe jednotlivé formy terénní výuky $v$ daném předmětu navazují a jsou postupně rozvíjeny, jestli existují mezipředmětové vazby, nebo ucelený systém dlouhodobých forem terénní výuky. Výše v textu (oddíl 1) jsme nastínili pojetí koncepčního př́stupu k terénní výuce. $Z$ analýzy vyplývá, že terénní výuka takto pojímána $v$ prevážné většině modelových škol není. Ve 40 př́padech není terénní výuka představena jako ucelená koncepce, pouze $v$ devíti případech se zdá pojata koncepčně $a v$ jednom př́padě nebylo možné tuto skutečnost posoudit.

Obdobný poměr odpovědí se ukázal i v následující otázce, která zjišt’ovala, zda je terénní výuka zmíněna v části ŠVP nazvané „učební plán“. Pouze ve 13 případech byla $v$ učebním plánu zmínka o terénní výuce, zatímco $v 36$ př́padech nebyla. $V$ jednom př́padě dokonce nebyla část „učební plán“ v ŠVP identifikována. 
Pokud $v$ učebním plánu zmínka o terénní výuce byla, bylo následně zjišt’ováno, $\checkmark$ jaké vzdělávací oblasti byla terénní výuka uvedena. Součet uvedených odpovědí nedává součet 50 , jelikož bylo možné uvést více variant současně.

$\mathrm{Na} 1$. stupni ZŠ byla terénní výuka zastoupena $9 \times$ ve vzdělávací oblasti Člověk a jeho svět, která je jako jediná koncipována pouze pro 1 . stupeň základního vzdělávání. U některých ŠVP pak byly zastoupeny konkrétní předměty - prvouka, vlastivěda a prírodověda.

Z dalších vzdělávacích oblastí byly $12 \times$ zastoupeny vzdělávací oblasti Člověk a príiroda (konkrétní předměty zeměpis a přirodopis) a Člověk a zdraví (předměty výchova ke zdraví a tělesná výchova). Celkem $7 \times$ byla uvedena vzdělávací oblast Člověk a společnost (předměty dějepis a výchova $k$ občanství) a $3 \times$ Člověk a svět práce. U šesti dalších odpovědí byla terénní výuka zastoupena jinak než ve vzdělávací oblasti, a to např. formou projektu, školní družiny nebo kurzů.

Daleko častěji je terénní výuka zmiňována v části ŠVP nazvané „učební osnovy“. Ve 49 př́padech z 50 je terénní výuka zmíněna, v jednom ŠVP nebyly učební osnovy identifikovány. $V$ učebních osnovách byla terénní výuka nejčastěji identifikována $v$ předmětech zeměpis a přirodopis, kde se nejčastěji jednalo o přímou práci v terénu (kupř. orientace podle mapy, pozorování či sběr rostlin). $V$ př́padě předmětů dějepis, český jazyk a občanská výchova byly nejčastěji identifikovány exkurze do muzeí, knihoven nebo úřadu. Co se týče hudební a výtvarné výchovy, až na výjimky se rovněž jednalo o exkurze, konkrétně o návštěvy filmových a divadelních představení, koncertů a výstav, v př́padě výtvarné výchovy ojediněle i o kresbu v plenéru. U předmětů výchova ke zdraví a tělesná výchova se terénní výuka objevuje nejčastěji ve formě dlouhodobých sportovních kurzů, ale také ve formě pobytu a turistiky $v$ prírodě. Ostatní předměty využívají terénní výuku velmi zř́dka, a to ve snaze sblížení teorie a praxe (např. měření reálných veličin $v$ terénu $v$ matematice či fyzice).

Mezipředmětovost terénní výuky. Při hodnocení zařazení terénní výuky z předmětového hlediska se ukázalo, že ve 29 př́padech lze identifikovat v ŠVP zároveň předmětovou 3 i integrovanou formu terénní výuky. Ve všech případech mezipředmětové výuky se jednalo o propojení tematicky blízkých předmětů, nejčastěji zeměpisprírodopis, zeměpis-dějepis, což však nebylo uvedeno v popisu učiva, ale v popisu vzdělávací oblasti. Jak konkrétně je mezipředmětovost ve výuce aplikována, nelze $z$ ŠVP vyčíst. $V$ dalších 20 prípadech pak byla uvedena pouze terénní výuka zařazená $v$ jednotlivých předmětech. Pouze $v$ jednom prípadě byla uvedena integrovaná terénní výuka.

Poměrně zajímavé je zařazení terénní výuky $v$ prưřezových tématech, kdy toto zařazení bylo identifikováno $v 28$ př́padech, $v 15$ př́padech naopak nebylo a $v$ sedmi případech nebylo možné zařazení průřezových témat posoudit. Př́i pohledu na zařazení terénní výuky do konkrétních průřezových témat je zřejmé, že do terénní výuky je možné začlenit všechna prưřezová témata. Nejvíce je však zastoupena environmentální výchova a dále osobnostní a sociální výchova. Ostatní prưřezová témata

3 Terénní výuka $v$ této podobě probíhá výhradně jako př́rodopisná nebo zeměpisná terénní výuka apod. 
106 jsou zastoupena méně, pouze jednou byla uvedena mediální výchova. O konkrétním způsobu uplatnění průřezových témat ve výuce většina ŠVP neposkytuje bližší informace. Prưřezová témata jsou pouze vyjmenována u daného předmětu, v některých př́padech pouze $v$ úvodu ŠVP.

Časové a prostorové hledisko terénní výuky. Z hlediska prostoru je terénní výuka v ŠVP nejčastěji (37 př́padů) pojata jako výuka v prostředí obce, ve které se daná škola nachází. $\vee 32$ př́padech byl jako místo pro terénní výuku volen venkov krajina a rovněž školní pozemek. V 10 případech nebylo možné prostor pro terénní výuku přesně určit. Pokud byla identifikována další místa, kde školy výuku v terénu pořádají, byla tato místa uvedena $v$ možnosti jiné. $\vee 17$ př́padech šlo o různé exkurze, kurzy (i sportovní) či návštěvy institucí nabízejících programy pro školy. Ve čtyřech př́padech byla uvedena škola v prrírodě nebo ekologický pobyt a také výjezd do zahraničí a ve dvou príipadech se jednalo o návštěvu sportovního zařizení (bazén, hřiště).

$Z$ hlediska času byla $v$ analyzovaných ŠVP nejčastěji - $v 35$ př́padech - identifikována krátkodobá terénní výuka, která probíhá jednu až dvě vyučovací hodiny - může se jednat o práce na školním pozemku či návštěvy výstav, muzeí apod. V 32 prípadech byla zjištěna dlouhodobá terénní výuka trvající dva a více dní, což jsou obvykle sportovní kurzy, výlety či pobyt ve výukových/ekologických střediscích. Nejméně často - ve 24 př́padech - byla zmiňována střednědobá terénní výuka, která trvá jeden vyučovací den. Je patrné, že takřka polovina modelových škol má v ŠVP uvedené všechny formy terénní výuky z hlediska času, ale také to, že je poměrně obtižné vymezit celý vyučovací den pouze pro jeden předmět nebo integraci předmětů v delší výukový blok, což usuzujeme z nejmenšího zastoupení střednědobých forem terénní výuky. $V 16$ prípadech nebylo možné délku trvání terénní výuky posoudit, jelikož v mnoha ŠVP není uvedena časová dotace a je nutné ji odhadovat na základě konkrétní aktivity, která může při rozdílné organizaci trvat několik hodin, ale i několik dní, např. v případě projektů.

Formy terénní výuky. Terénní výuka se $v$ analyzovaných ŠVP objevuje $v$ různých formách (počet výskytů jednotlivých forem je uveden na obrázku 2). Pro tyto formy neexistuje standardizované označení. Na př́kladu modelových škol je patrné, že mnohé školy si nazývají jednotlivé formy dle svých zvyklostí. Z analyzovaných ŠVP Ize identifikovat některá shodná označení forem terénní výuky nebo lze najít takové formy, které jsou si svým označením podobné, a tedy pravděpodobně blízké i svým obsahem.

Nejčastěji se $v$ analyzovaných ŠVP objevovala forma exkurze. Zde byly zahrnuty aktivity, jako je návštěva muzeí, knihoven, výstav, divadelních a filmových představení, planetária, zoologické zahrady apod. Exkurze jako výuková forma byla zmíněna u řady jednotlivých předmětů (např. český jazyk, hudební výchova, výtvarná výchova, prvouka), avšak často nebylo blíže určeno, kam se exkurze uskuteční, jakého učiva se týká, v kterém ročníku je zařazena atd.

Druhou nejčastější formou terénní výuky byla vycházka. Tato forma se $v$ jednotlivých ŠVP vyskytuje $v$ různých víceslovných označeních či souslovích: vycházka 
s pozorováním, vycházka do přírody, zeměpisná vycházka s pozorováním, terénní vycházka, př́rodovědná vycházka, vzdělávací vycházka.

Další častou terénní výukovou formou, která má stejně jako předchozí forma $\checkmark$ jednotlivých ŠVP mnoho odlišných slovních označení, je terénní cvičení. $V$ analyzovaných ŠVP najdeme tato pojmenování: terénní vyučování, praktické cvičení $\checkmark$ terénu, $v$ prírodě, terénní praxe, terénní výuka, terénní geografická výuka, integrované terénní vyučování, práce $v$ terénu, prrírodovědné terénní vyučování, výuka $v$ terénu, $v$ prírodě.

$\checkmark$ ŠVP byly dále identifikovány, oproti předchozím zmíněným formám poměrně zřejmé, kategorie: školní výlet, škola $v$ prírodě, adaptační/seznamovací pobyt.

Další velkou skupinou jsou sportovně zaměřené formy výuky $v$ terénu. Zde byly vymezeny dvě kategorie. První kategorie se týká sportovních kurzů/pobytů, kde se předpokládá dlouhodobá forma výuky (vícedenní terénní výuka s pobytem mimo domov). Jedná se o: lyžařské výcvikové kurzy, letní výcvikové kurzy (vodácký, cyklistický apod.) či ozdravné pobyty. Do druhé kategorie označené jako dalši sportovní aktivity byly zařazeny krátkodobé sportovní aktivity, které se objevují v následujících podobách: pobyt $v$ terénu, pobyt $v$ prrírodě, turistika $v$ př́rodě, pochodové cvičení, hry v přírodě, plavecký výcvik, bruslení, sáňkování apod.

V ŠVP škol, které jsou většinou zaměřeny na jazykové vzdělávání, podporují studijní výměnné pobyty či jakkoli spolupracují se zahraničními školami, byla identifikována forma zahraniční zájezd / studijní pobyt. Do kategorie školní zájezd byly zahrnuty formy označované jako tematické zájezdy či školní vlastivědné zájezdy.

Forma práce na pozemku/zahradě, která je většinou součástí pracovních činností, byla identifikována u sedmi škol. Pro úplnost zmiňme jako poslední terénní formu dopravní výuku realizovanou na dopravním hřišti. Žádná ze škol neměla uvedenou jinou výuku na školním pozemku, jak ji již na sklonku sedmdesátých let definoval

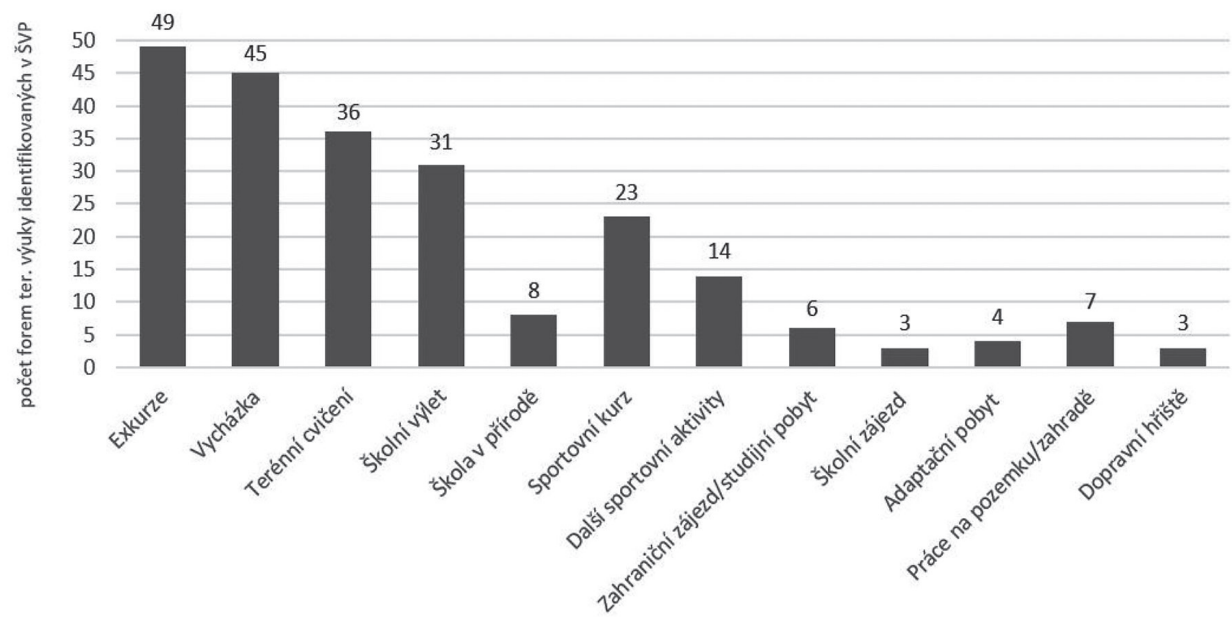

Obrázek 2 Realizované formy terénní výuky identifikované v ŠVP 


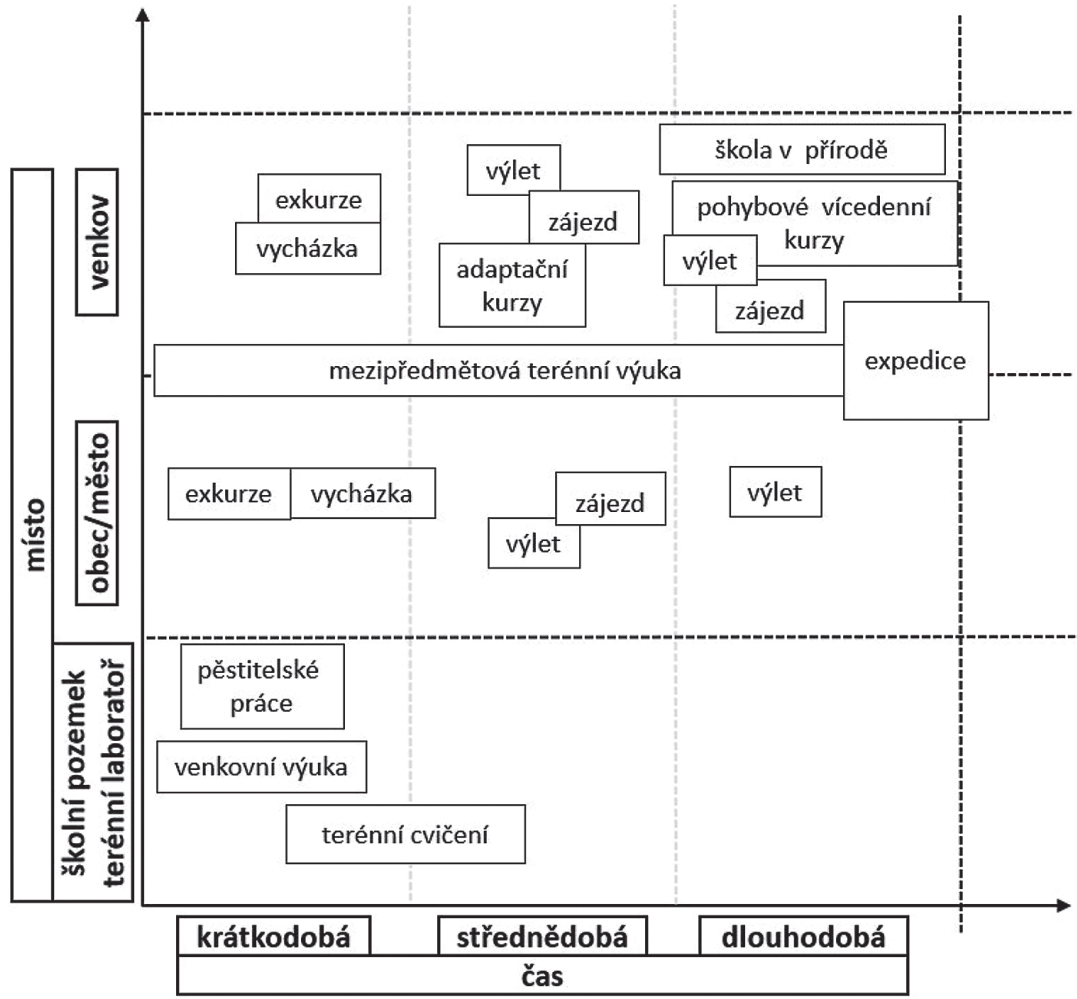

Obrázek 3 Rozdělení forem terénní výuky vzhledem k času a místům jejich realizace

např. Papík (1979, s. 217) - v zeměpise se jedná např. o měření směru a síly větru, pozorování počasí či měření vzdáleností.

Ve snaze provést korelaci mezi časem a prostorem realizace terénní výuky vznikl obrázek 3, který představuje redukované formy terénní výuky, jež vycházejí $z$ analýzy sledovaných ŠVP. Je z něj zřejmé, že krátkodobé formy terénní výuky se uskutečňují v územích, která jsou škole blízká a kam se dá v rámci jedné až dvou vyučovacích hodin přemístit. Proto u krátkodobých forem terénní výuky převažuje práce na školním pozemku nebo terénní výuka v prostředí obce. Střednědobé formy jsou uplatňovány nejméně, $z$ hlediska prostoru převládá prostředí obce, pro krátké jednodenní výlety se může jednat i o prostředí venkova. Prostředí venkova / volné krajiny jasně převládá u dlouhodobých forem terénní výuky, jako jsou různé terénní kurzy.

\subsection{Rozhovory s učiteli}

Výsledky obsahové analýzy ŠVP bylo nutné doplnit a detailně upřesnit prostřednictvím strukturovaných rozhovorů s učiteli 1 . a 2 . stupně základních škol. Jak z analýzy 
ŠVP, tak z rozhovorů vyplynulo, že učitelé v různé míře i rozsahu využívají rozmanité formy terénní výuky. Rozhovory pomohly především upřesnit jednotlivé formy terénní výuky, jejich délku a obsah. Na 1. stupni má terénní výuka často prưřezový charakter a je řazena do vzdělávací oblasti Člověk a jeho svět. Na 2. stupni se pak nejčastěji využívají některé formy terénní výuky $v$ př́rodopise a zeměpise. Učitelé na 1. stupni mají oproti 2 . stupni tu výhodu, že učitel učí ve třídě téměř všechny předměty, lze je vhodně propojit, a tudíz se také aktivity $v$ terénu mohou prolínat více předměty.

Koordinace terénní výuky. Rozhovory ukázaly, že přehled o uskutečňovaných formách terénní výuky v modelových školách má nejčastěji zástupce ředitele, v některých př́padech také koordinátor EVVO. Rámcově se tento přehled může vyskytovat $v$ ŠVP či učebním plánu, ojediněle byl tento přehled zahrnut také do výroční zprávy školy (nicméně se tak $\mathrm{k}$ učitelům dostal až zpětně). Přibližně polovina dotazovaných učitelů uvedla, že má přehled o uskutečňovaných formách terénní výuky ve své škole. Podobná situace nastala také u otázky zda: někdo koordinuje ve škole všechny formy terénní výuky tak, aby tvořily ucelenou koncepci. Vyplynulo, že učitelé považují za ucelenou koncepci to, co je uvedeno v ŠVP nebo plánu EVVO (pokud existuje), kde jsou uvedeny každoročně se opakující aktivity školy. Za ucelenou koncepci je $v$ některých případech považován též roční (týdenní) učební plán nebo přehled předmětové komise. $Z$ analýzy ŠVP však rovněž plyne, že zde obvykle nejsou uvedeny krátkodobé formy terénní výuky, čímž není splněna podmínka ucelené koncepce, která zahrnuje a propojuje všechny dílčí formy terénní výuky. Ukazuje se, že domluva mezi jednotlivými učiteli probíhá snadněji v malých školách, koordinace ve velkých školách (s početným kolektivem pedagogů) je obtížnější. Jeden z učitelů uvedl, že „neexistuje žádná obecná konceptuální metodika - doporučení pro terénní výuku“.

Hodinová dotace terénní výuky. U otázky zjišt’ující hodinovou dotaci terénní výuky uvedla většina učitelů, že všechny formy terénní výuky nejsou zapracovány do tematických plánů jejich předmětů s vyjádřením hodinové dotace. Na základě výpovědí se však lze domnívat, že vyjádřeny jsou spíše hodinové, respektive denní dotace pro dlouhodobé formy terénní výuky, které se každoročně opakují, např. výrok „je tam uveden týden, týdenní výjezd“ $v$ př́padě terénního kurzu. $Z$ takových údajů není patrné, kolik času denně stráví žáci výukou/odpočinkem apod. Zajímavé je, že z rozhovorů v podstatě vyplynulo, že učitelé spíše hovoři o projektech školy než o terénní výuce zařazené přímo $\mathrm{k}$ jednotlivým vyučovacím předmětům $\mathrm{s}$ vyjádřením hodinové dotace.

Formy terénní výuky. Dotazovaní učitelé využívají v jimi vyučovaných předmětech různé formy terénní výuky. Pro krátkodobé formy terénní výuky je z pohledu učitelů 2 . stupně zásadní, aby se učitel s žáky stačil za 45 minut přemístit $z$ učebny do terénu a zpět. Toto je zároveň jeden z limitujících faktorů krátkodobých forem terénní výuky u učitelů 2 . stupně, jelikož musí harmonogram výuky „sladit“ s mnoha dalšími kolegy. Naproti tomu učitelé 1 . stupně tento problém nepocit'ují - učí většinu předmětů $v$ dané třídě, a mohou tak daleko efektivněji nakládat $s$ časem 
110 vymezeným pro výuku. Mají výhodnější výchozí pozici pro integraci vzdělávacího obsahu různých předmětů a rovněž k rozvržení výuky, včetně zahrnutí krátkodobých forem terénní výuky (tematické školní vycházky zaměřené na sběr hmyzu, zakládání herbáře, orientaci v krajině apod.). Pokud jsou $k$ dispozici, jsou pro tyto účely využívány i školní pozemky, nebo $v$ prípadě měst parky. Tyto krátkodobé formy terénní výuky však $v$ podstatě nejsou $v$ jednotlivých ŠVP uváděny. $V$ ŠVP (případně v plánu EVVO) jsou uvedeny pouze „zavedené“ každoročně se opakující akce školy - např. projektové dny. Z hlediska krátkodobých forem terénní výuky se objevuje nejčastěji vycházka. Ze střednědobých forem lze identifikovat exkurze, výlety, návštěvy muzeí, projektové dny, ale také třeba návštěvu nemocnice, záchranné stanice, kurzy první pomoci nebo výukové programy organizované ve spolupráci s externími subjekty (např. Lipka, hasiči, správa městských lesů). Dlouhodobé formy terénní výuky (s délkou přesahující jeden den) se objevují v podobě terénních výcvikových kurzů (lyžařské, vodácké, cyklistické), vícedenních výletů, řidčeji už jsou zastoupena komplexní cvičení v terénu.

Koncepce terénní výuky. Další otázkou bylo zjištováno, zda oslovení učitelé mají ve svých předmětech vytvořenou ucelenou koncepci terénní výuky, jejiž formy na sebe navazují (horizontálně i/nebo vertikálně). Počet kladných i záporných odpovědí byl vyrovnaný. Učitelé 1 . stupně podpořili svůj kladný výrok tím, že koncepce je dána především tematickými plány pro jednotlivé ročníky. V rozhovorech se ukázalo, že někteři učitelé mohou chápat koncepci jako takové formy terénní výuky, které se každoročně opakují (exkurze, výlety, pobyty $v$ prírodě, environmentální programy). Pouze $v$ jedné škole si učitelé vytvořili koncepci terénní výuky společně a tato koncepce je podpořena vytvořením tzv. portfolia pro terénní výuku.

Mezipředmětovost a spolupráce učitelů. Na otázku, jestli učitelé realizují některé formy terénní výuky ve spolupráci s učiteli jiných předmětů, odpovědělo kladně více učitelů 1 . než 2 . stupně. Spolupráce na 1 . stupni se tedy může jevit jako snadnější, zde je však možné interpretovat odpovědi trojím způsobem: 1) Učitel na 1. stupni vyučuje ve své třídě všechny předměty a navazuje tak $v$ podstatě sám na sebe, spolupracovat s dalšími učiteli tudíž nepotřebuje (zde se domníváme, že měl být postoj vyjádřen spíše odpovědí „ne“). 2) Učitelé spolupracují pouze při zajištění dozoru a bezpečnosti při přesunech žáků, např. do hvězdárny, na výcvikové kurzy apod. 3) Učitelé spolupracují na projektech na 1 . stupni nebo $v$ rámci celé školy (např. Den Země): Problémem je vzájemná domluva učitelů: „,... chodíme pouze individuálně, domlouvat se je př́liš složité. “ Další učitel okomentoval situaci následovně:

„... plánování školy v přírodě, případně příprava lyžařského výcvikového kurzu, a ještě $\checkmark$ rámci ročníku se společně domlouváme na exkurzích, takže spojíme třídy, nebo to aspoň domlouváme tak, aby to všichni v tom ročníku absolvovali, že si o tom dáváme vědět. Ono to potom třeba neproběhne, ale to plánování je společné i třeba kvůli fakturám.“

$\mathrm{Na} 2$. stupni učitelé spolupracují při realizaci krátko- a střednědobých forem terénní výuky. Jako příklad uved’me exkurzi na Moravskou Saharu, na které participuje 
více učitelů, z nichž každý odborně pokrývá část exkurze (dějepisná, zeměpisná, př́rodopisná část + pohybové aktivity).

Výběr témat pro terénní výuku. Následující část rozhovoru se týkala způsobu výběru témat pro terénní výuku a výběr témat v př́mé návaznosti na výuku ve škole. Všichni dotázaní učitelé uvedli, že mají určitý způsob výběru témat pro terénní výuku. Rovněž se všichni učitelé snaži při terénní výuce navazovat na výuku ve škole. Z rozhovorů vyplývá, že konkrétní téma terénní výuky se odvíjí jak od aprobace, tak od osobních preferencí učitele („každý dělá nejraději to, co je mu blízké“) a nabídky regionu (místní zvyky a tradice). $V$ dalších odpovědích zazněla vazba na externí subjekty, které nabízejí vlastní témata pro terénní výuku. Zde je podle výpovědí důležitá předchozí pozitivní zkušenost s těmito subjekty. Jeden učitel uvedl, že si témata pro terénní výuku vybírá tam, „kde si myslím, že jim (pozn. žákům) to dá $v$ terénu více než ve třídě“. Další učitel odpověděl, že je důležité „zaujmout žáky nějakou akční strategii““. Za klíčovou považujeme poznámku, že při výběru témat pro terénní výuku je důležitá zejména „snaha to těm žákům zpestřit a ukázat jim, že to funguje $v$ praxi, že se neučí jenom proto, aby to uměli nazpamět', ale že se jim to třeba může hodit dál někde $v$ životě v praxi“. Také zde byla zmíněna role počasí, obecně se častěji chodí do terénu na jaře a na podzim, méně v zimě.

Učitelé 1. i 2 . stupně modelových škol nejčastěji vybírají pro terénní výuku konkrétní náměty z reálného života. Pouze výjimečně nevyužívají aktuální téma. Učitelé hledají nejčastěji inspiraci v okolí školy, obce nebo regionu. Zejména v menších obcích je život školy propojen s životem obce a žáci se aktivně podílejí na kulturních a dalších akcích a mohou na území obce provádět řadu činností: ,„... čištění okolí řeky Dyje a sbírání odpadků, dotazníkový průzkum žáků mezi občany obce, tvorba naučné stezky, měření teploty a pH vody (půdy, vzduchu), účast žáků na tzv. kulatých stolech pořádaných obcí...“

Př́prava učitele na výuku $v$ terénu. $V$ dalši části se rozhovor zaměřil na přípravu terénní výuky, tedy zda si učitelé dělají podrobné př́pravy na práci v terénu. Všichni dotázaní učitelé odpověděli kladně. Někteří učitelé zdưrazňují, že příprava na terénní výuku musí být zvlášt' pečlivá, protože: ,,... ve frontálce můžu vždycky zaimprovizovat, ale když jim dám špatné údaje na stanovištích, tak už to zpátky vzít nejde. "Někteří učitelé používají pracovní listy, jejichž význam popisují jak ve vztahu $\mathrm{k}$ žákům (strukturuje požadavky učitele), tak ve vztahu k učiteli (má určitý výstup výuky). Jeden z učitelů dodává, že každá aktivita musí mít své zaměření a jasný cíl, aby si žáci nemysleli, že terénní výuka je jen vycházka. Učitelé na 1. stupni dodávají, že terénní výuka by pro mladší žáky měla být zábavná, může mít nějakou zápletku a být realizována formou hry, což žáky motivuje. Některé školy mají zpracováno tzv. portfolio terénní výuky, které obsahuje sadu pracovních listů, map a dalších pomůcek. Učitelé dále zdůrazňují, že při plánování terénní výuky je důležitá znalost místa. Pokud je to možné, považují za vhodné si zájmovou lokalitu předem projít (např. zjistit výskyt rostlinných druhů pro tvorbu herbáře). U celodenních exkurzí je pak nutné připravit i přibližný časový harmonogram. Minimální je poté př́prava učitelů při spolupráci s externím subjektem. 
112 Bariéry realizace terénní výuky. Rozhovor dále ukázal, že většina učitelů 1. stupně a všichni učitelé 2 . stupně cítí určitá omezení při přípravě terénní výuky. $\mathrm{Na}$ 1. stupni se objevují omezení odlišného charakteru než v př́ípadě 2 . stupně. $Z$ uváděných omezení lze jmenovat např. neochotu financování terénní výuky ze strany některých rodičů, zajištění bezpečnosti žáků, počasí, př́ípadně neochota žáků vyrazit do terénu spojená s vyrušováním i snižující se tělesná kondice žáků. Na fenomén klesající fyzické zdatnosti žáků poukazovali učitelé např́í výzkumným vzorkem a je pozorován i v mezinárodním měřítku, viz např. rozsáhlá studie Health Behaviour in School-Aged Children (Inchley et al., 2016). Uváděna je také vyšší náročnost na př́pravu (která není nijak oceněna) a určité časové omezení. $V$ jednom př́padě byla uvedena absence terénní učebny. Na 2. stupni je za významnou bariéru považována hodinová dotace předmětu. Pokud chce učitel na terénní výuku vyčlenit více než jednu hodinu výuky (s prèedpokladem přesunu do lokality a návratu zpět), naráží na již zmiňovaný problém komunikace $s$ ostatními učiteli a obtiže $s$ výměnou hodin. Dalším výrazným problémem je administrativa spojená s realizací terénní výuky. Kromě zajištění dalšího učitele na dohled, je u dlouhodobých forem často nezbytný souhlas rodičů. Jeden z učitelů upozornil i na fakt, že pokud by chtěl být víc hodin $v$ terénu, musí si zajistit i výměnu dozorů o přestávkách. $V$ př́padě středně- a dlouhodobých forem terénní výuky je také nutné vypořádat se s náhradou hodin ostatních předmětů. Za závažné považujeme vyjádření jednoho učitele, který v kontextu své školy uvedl, že „,hodiny odučené $v$ terénu se nepočítají jako odučené (!), a tak učitel pak musí např. suplovat zadarmo“. A to i v př́padě, že se učitel s žáky vrací $z$ terénní výuky až pozdě večer nebo tato výuka trvá vícero dní. U některých akcí je problémem i nezájem žáků (lyžařský výcvikový kurz). Podle výpovědí učitelů ovšem akce podobného typu narážejí u některých žáků spiše na neochotu k pohybu (viz výše).

Pomůcky pro terénní výuku. Na otázku zjišt'ující dostupnost základních pomůcek pro terénní výuku v modelových školách odpovídali učitelé kladně, to znamená, že většinu potřebných pomůcek mají $k$ dispozici. Učitelé mezi dostupné pomůcky zařadili nejčastěji kompasy/buzoly a mapy. Některé školy disponují i dalšími pomůckami: lupy, ekologické batohy, archiv pracovních listů (portfolio), sportovní pomůcky, měřicí systém Pasco (který však není využíván z důvodu časové náročnosti při prostřídání žáků u přístroje), sít'ky, cedítka, dalekohledy, mikroskopy, zalaminované mapy, lékárničky, GPS. Jedna škola uvedla spolupráci se střediskem, kde je možné pomůcky zapůjčit.

\section{Diskuse a závěr}

První fáze výzkumu prokázala, jak se jednotlivé ŠVP liší svou kvalitou, rozsahem, detailností a dalšími charakteristikami (viz výše). Některé ŠVP obsahují podrobný popis učiva a jiné v podstatě jen plní funkci nezbytného dokumentu (srov. Píšová, Kostková, \& Vlček, 2011, s. 28). Tato různorodost se potvrdila také v implementaci 
terénní výuky do ŠVP. V analyzovaných ŠVP se objevují rozličné pojmy, které lze dát do souvislosti s terénní výukou, mnohé školy si však nazývají tyto formy dle svých zvyklostí a teprve rozhovory s učiteli upřesnily, jakým způsobem je daná forma terénní výuky $v$ modelové škole pojata. $V$ úvodních částech ŠVP jsou často zmíněné některé z forem terénní výuky, jako je např. exkurze či výuka v terénu. Avšak nelze vyčíst bližší specifika, jako kam se exkurze uskuteční, jakého učiva se týká, ve kterém ročníku je plánováno její zařazení atd.

Při rozhovorech se ukázalo, že učitelé 1 . stupně považují svou výchozí pozici k rozvržení výuky za výhodnější (ve srovnání s učiteli 2 . stupně), včetně zahrnutí krátkodobých forem. Pro účely krátkodobých forem terénní výuky jsou využivány školní pozemky, nebo $v$ př́padě měst např. parky. Tyto krátkodobé formy terénní výuky však často nejsou v jednotlivých ŠVP uváděny.

Na základě analýzy ŠVP ani při rozhovorech s učiteli tedy nebyla odhalena žádná progrese učiva, respektive aktivit využívaných při terénní výuce (viz tabulka 1). Z analýzy ŠVP nelze v podstatě žádnou progresi aktivit terénní výuky hodnotit, jedná se pouze o výčet různých forem terénní výuky, ale skutečný cíl nebo obsah uveden není. $Z$ výpovědí učitelů pak vyplývá, že $v$ popředí zájmu jsou dlouhodobé formy terénní výuky ve formě každoročně se opakujících kurzů/projektů a terénních cvičení, ty však nijak nenavazují na krátkodobé formy terénní výuky, které jsou obvykle realizovány $v$ okolí školy a řeší témata blízkého okolí školy. Vzhledem $k$ tomu, že střednědobé formy terénní výuky jsou řazeny nejméně často, pak v řadě škol tento článek terénní výuky zcela chybí.

Vazba na probírané učivo z analýzy ŠPV rovněž nevyplývá. Některé návaznosti terénní výuky na výuku ve třídě poodhalily rozhovory s učiteli. $V$ prípadě krátkodobých forem terénní výuky je možné na učivo ve škole snadno navázat, učitelé volí témata, která jim nabízí region a jejich oborové zaměření. U dlouhodobých forem výletů a kurzů - se obvykle jedná pouze o poznání daného místa a jeho historie bez návaznosti na výuku ve tř́dě.

Některé bariéry realizace terénní výuky na 2 . stupni v Česku se jeví jako podobné těm, které byly $v$ minulosti identifikovány $v$ zahraničí. Prvotní výsledky naznačují, že podobnosti jsou patrné zejména u obav o bezpečnost žáků při terénní výuce, dále pak ve vnímání administrativní, finanční a časové náročnosti (srov. Remington \& Legge, 2016; Rickinson et al., 2004; Waite, 2009). Další jmenované bariéry mohou být specifické spiše pro naše školství (nezapočítávání hodin do výuky, nahrazování výuky apod.) $V$ rámci realizovaných rozhovorů byla také identifikována novodobá bariéra - klesající fyzická zdatnost žáků, jejíž význam do budoucna bude pravděpodobně v souvislosti se snižující se pohybovou aktivitou žáků (srov. Lee, Stodden, \& Gao, 2016; Madarasová Gecková et al., 2016; Mužík \& Krejčí, 1997) nabývat na významu.

Odpověd' na výzkumnou otázku: Je formální stránka terénní výuky na základní škole pojata koncepčně? - nebylo možné zjistit pouze na základě obsahové analýzy ŠVP. U řady výstupů uvedených $v$ ŠVP a učiva není možné přesně určit, $v$ jakých formách je terénní výuka do výuky řazena a jak je skutečně pojata. Prvotní výsledky 
114 spiše naznačily nízkou provázanost jednotlivých forem terénní výuky. Až následující rozhovory ukázaly, že terénní výuka je v modelových základních školách pojata spíše nekoncepčně, jednotlivé formy terénní výuky na sebe nenavazují ani se vzájemně nedoplňují. Ukázalo se také, že ačkoli terénní výuka bývá často uplatňována rưznými formami, nevykazuje vždy mezipředmětový ani integrující charakter a často se využívá pro její realizaci tzv. projektů, kterými školy nazývají své rozličné pravidelně se opakující akce.

Př́spěvek představil první část výzkumu a dílči závěry. Výzkum bude pokračovat dalšími kroky. $V$ teoretické rovině dojde $k$ terminologickému vymezení forem terénní výuky a dále bude navržen optimální systém organizace terénní výuky v základních školách. Stěžejní částí pak bude testování/měření přínosů terénní výuky k rozvoji kompetencí žáků $\mathrm{k}$ řešení úkolů a také $\mathrm{k}$ rozvoji pohybové aktivity žáků. $V$ dílčí části pak budou hodnocena také pozitiva a negativa terénní výuky, vnímaná ze strany žáků, rodičů a učitelů.

\section{Literatura}

Biddulph, M., Lambert, D., \& Balderstone, D. (2015). Learning to teach geography in the secondary school: A companion to school experience. (3rd ed.). Abingdon: Routledge.

Creswell, J. W., \& Plano Clark, V. L. (2011). Designing and conducting mixed methods research (2nd ed.). Los Angeles: SAGE.

Česká školní inspekce (2012). Analýza školních vzdělávacích programů pro základní vzdělávání za období 2007-2011 [Tematická zpráva]. Praha: autor. Dostupné z http://www.csicr.cz /getattachment/81ecf1bd-9e36-4298-817a-3fc2ecc6198c

Činčera, J. (2011). Rozvoj výzkumných kompetencí žák na základní škole: zkušenosti z evaluace programu o Jizerských horách. Envigogika, 6(3), 1-13.

Činčera, J., \& Holec, J. (2016). Outdoor education in formal education. Envigogika, 11(2).

Činčera, J., \& Mašková, V. (2011). GLOBE in the Czech Republic: A program evaluation. Environmental Education Research, 17(4), 499-517.

Gavora, P. (2000). Úvod do pedagogického výzkumu. Brno: Paido.

Hay, I. (2010). Qualitative research methods in human geography (3rd ed.). Oxford: Oxford University Press.

Hendl, J. (2012). Kvalitativní výzkum: základní teorie, metody a aplikace (3. vyd.). Praha: Portál.

Hofmann, E., et al. (2003). Integrované terénní vyučování. Brno: Paido.

Hofmann, E., Rychnovský, B. \& Borecký, D. (1999). Organizace a přinos terénního vyučování 2. Biologie, chemie, zeměpis, 8(4), 196-197.

Hopkins, D. (2000). Powerful learning, powerful teaching and powerful schools. Journal of Educational Change, 1(2), 135-154.

Inchley, J. C., Currie, D. B., Young, T. et al. (Eds.). (2016). Growing up unequal: Gender and socioeconomic differences in young people's health and well-being: Health Behaviour in School-aged Children (HBSC) study: international report from the 2013/2014 survey. (Health Policy for Children and Adolescents; No. 7.) Copenhagen: WHO Regional Office for Europe.

Jelínek, P., \& Kysučan, L. (2014). Venkov a krajina: evropská krajina mezi venkovem a městem, mezi antikou a novověkem. Brno: MU.

Karvánková, P., Popjaková, D., Vančura, M., \& Mládek, J. (Eds.). (2017). Current topics in Czech and Central European geography education. Switzerland: Springer International Publishing, Springer Nature. 
Kent, M., Gilbertson, D. D., \& Hunt, C. O. (1997). Fieldwork in geography teaching: A critical review of the literature and approaches. Journal of Geography in Higher Education, 21(3), 313-332.

Knecht, P., \& Hofmann, E. (2013). K problému řazení geografického učiva ve školních vzdělávacích programech. Informace České geografické společnosti, 32(2), 13-25.

Kratochvíl, M., Solfronk, J., \& Urbánek, P. (2002). Základy didaktiky: studijní texty pro distanční studium. Liberec: TUL.

Kvasničák, R. (2013). Krátkodobý vplyv skúsenostného vyučovania v teréne na vedomosti žiakov o ekosystéme. Pedagogika, 63(2), 198-219.

Kvasničák, R., Prokop, P., \& Pištová, Z. (2005). Krátkodobý vplyv skúsenostného vyučovania $\checkmark$ teréne na vedomosti žiakov o ekosystéme. E-Pedagogium, 5(4), 28-36.

Lambert, D., \& Balderstone, D. (2010). Learning to teach geography in the secondary school: A companion to school experience (2nd ed.). New York: Routledge.

Lambert, D., \& Reiss, M. J. (2014). The place of fieldwork in geography and science qualifications. London: Institute of Education, University of London.

Lee, J. E., Stodden, D. F., \& Gao, Z. (2016). Young children's energy expenditure and moderate-to-vigorous physical activity on weekdays and weekends. Journal of Physical Activity and Health, 13(9), 1013-1016.

Madarasová Gecková, A., Dankulincová, Z., Sigmundová, D., \& Kalman, M. (Eds). (2016). Mezinárodní zpráva o zdraví a životním stylu dětí a školáků na základě výzkumu studie Health Behaviour in School-Aged Children realizované v roce 2014. Olomouc: UP.

Marada, M. (2006). Jak na výuku zeměpisu v terénu? Geografické rozhledy, 15(3), 2-5.

Mrázková, K. (2011). Kartografické dovednosti ve výuce zeměpisu: teoretický model a výsledky výzkumného šetření. In T. Janík, P. Najvar, \& M. Kubiatko, et al., Kvalita kurikula a výuky: výzkumné př́stupy a nástroje (s. 193-205). Brno: MUNI PRESS.

Mužík, V., \& Krejčí, M. (1997). Tělesná výchova a zdraví. Olomouc: Hanex.

Office for Standards in Education (Ofsted). (2011). Geography: Learning to make a world of difference. Dostupné z http://www.ofsted.gov.uk/resources/geography-learning-make-world-of-difference

Oost, K., De Vries, B., \& Van der Schee, J. A. (2011). Enquiry-driven fieldwork as a rich and powerful teaching strategy - school practices in secondary geography education in the Netherlands. International Research in Geographical and Environmental Education, 20(4), 309-325.

Papík, M. (1979). Vyučovacie prostriedky zemepisu. In J. Turkota, H. Fričová, J. Charvát, M. Papík, J. Šupka, \& A. Wahla, Základy všeobecnej didaktiky geografie. Bratislava: SPN.

Petty, G. (1996). Moderní vyučování: praktická příručka. Praha: Portál.

Píšová, M., Kostková, K., \& Vlček, P. (2011). Kurikulární reforma na gymnáziích: případové studie. In T. Janík, P. Knecht, \& S. Šebestová (Eds.), Smíšený design v pedagogickém výzkumu: Sborník příspěvků z 19. výroční konference České asociace pedagogického výzkumu (s. 24-30). Brno: MU.

Průcha, J. (1992). Pedagogické teorie a výzkumy na Západě. Praha: Karolinum.

Průcha, J., Walterová, E., \& Mareš, J. (2013). Pedagogický slovník (7. vyd.). Praha: Portál.

Remington, T., \& Legge, M. (2016). Outdoor education in rural primary schools in New Zealand: A narrative inquiry. Journal of Adventure Education and Outdoor Learning, 17(1), 55-66.

Rickinson, M., Dillon, J., Teamey, K., Morris, M., Choi, M. Y., Sanders, D., Benefield, P. (2004). A review of research on outdoor learning. London: National Foundantion for Educational Research, King's College.

Řezníčková, D. (2008). Náměty pro geografické a environmentální vzdělávání: Výuka v krajině. Praha: PřF UK.

Samková, L., Hošpesová, A., Roubíček, F., \& Tichá, M. (2015). Badatelsky orientované vyučování v matematice. Scientia in educatione, 6(1), 91-122. Dostupné z http://www.scied. $\mathrm{cz/index.php/scied/article/viewFile/154/145}$

Smetáčková, I. (2011). Škola v přírodě: limity a dilemata. Pedagogická orientace, 21(4), 416-135. 
116 Tejeda, R., \& Santamaría, I. (2010). Models in teaching: A powerfull skill. In Proceedings of the 7th WSEAS International conference on engineering education (pp. 77-85). Sofia: World Scientific and Engineering Academy and Society (WSEAS).

Waite, S. (2009). Outdoor learning for children aged 2-11: Perceived barriers, potential solutions. In Fourth International Outdoor Education Research Conference (pp. 15-18). Victoria: La Trobe University, Beechworth.

Záleský, J. (2009). Terénní výuka. Geografické rozhledy, 19(2), 14-17.

Žák, M. (2011). Jaký má vliv úvodní soustředění (neboli adaptační kurz) na kvalitu sociálních vztahů ve třídním kolektivu. Gymnos Akadémos, 1(2), 28-42.

RNDr. Hana Svobodová, Ph.D., katedra geografie Pedagogická fakulta, Masarykova univerzita

Poříčí 7, 60300 Brno hsvobodova@ped.muni.cz

Mgr. Radek Durna, katedra geografie Pedagogická fakulta, Masarykova univerzita Poříćí 7, 60300 Brno durna@mail.muni.cz

Mgr. Darina Mísařová, Ph.D., katedra geografie Pedagogická fakulta, Masarykova univerzita Pořičí 7, 60300 Brno misarova@ped.muni.cz

doc. PaedDr. Eduard Hofmann, CSc., katedra geografie Pedagogická fakulta, Masarykova univerzita Pořićí 7, 60300 Brno hofmann@ped.muni.cz 